\title{
ANALISIS LINGKUNGAN, KESEHATAN, DAN KESELAMATAN KERJA (LK3) (STUDI KASUS DI PT. RAVANA JAYA)
}

\author{
Achmad Najibur Rochman ${ }^{1}$, Deny Andesta ${ }^{2}$, dan Elly Ismiyah ${ }^{3}$ \\ Program Studi Teknik Industri, Fakultas Teknik, Universitas Muhammadiyah Gresik \\ Jl. Sumatera 101 GKB, Gresik 61121, Indonesia \\ Email:1yudhasatria20@gmail.com
}

\begin{abstract}
ABSTRAK
PT. Ravana Jaya merupakan perusahaan yang bergerak di bidang kontruksi yang membuat instalasi bangunan maupun kerangka bangunan, dalam pekerjaan di bidang kontruksi tidak lepas dari kemungkinan terjadinya kecelakaan kerja. Kecelakaan merupakan sesuatu peristiwa yang tidak direncanakan serta tidak diharapkan yang bisa mengganggu proses operasi, merusak harta benda, mencederai manusia, ataupun menggangu lingkungan. Maka dari itu dibutuhkan penerapan K3 di perusahaan konstruksi ataupun perusahaan-perusahaan lainnya. Penelitian ini bertujuan untuk mengidentifikasi bahaya atau resiko yang ada di area workshop PT. Ravana jaya dan seberapa besar tingkat bahaya tersebut. Sebelum mengendalikan bahaya sebaiknya perlu diketahui terlebih dahulu akar penyebab dari bahaya atau resiko tersebut. Berdasarkan permaslahan dari PT. Ravana jaya maka metode yang dapat digunakan adalah hazzard identification and risk assesment (HIRA) untuk mengidentifikasi bahaya dan juga sebagai penilaian tingkat resiko dan metode fault tree analyzis (FTA) untuk menganalisis akar penyebab terjadinya kecelakaan kerja. Dari hasil penelitian ini terdapat 28 identifiksai bahaya pada PT. Ravana Jaya. Dengan penilaian resiko sebagai berikut, 4 dengan kategori extreme risk (E), 18 dengan kategori high risk (H), 3 dengan kategori medium risk (M) dan 3 dengan kategori low risk (L). Akar penyebab dari kecelakaan kerja terdapat 2 aspek yaitu manusia dan lingkungan. Dari segi manusia pekerja kurang pengetahuan tentang K3 sehinga pekerja tidak disiplin memakai APD, serta kurangnya APD itu sendiri. Dari segi lingkungan kerja, area kerja, alat, dan material penataanya tidak teratur sehingga tidak ada jalan bagi pengguna jalan atau jalanya berubah-ubah.
\end{abstract}

Kata kunci : Konstruksi, Kecelakaan Kerja, K3, Lingkungan Kerja

\section{PENDAhULUAN}

Dalam era yang berkembang saat ini di Indonesia terdapat banyak sekali perusahaanperusahaan yang berkembang salah satunya perusahaan di bidang kontruksi, dalam pekerjaan di bidang kontruksi tidak lepas dari bahaya, resiko, dan kemungkinan terjadinya kecelakaan kerja. Menurut (Mandagi, 2013), (Rifani, 2018), dan (Alfons, 2013) salah satu pekerjaan yang paling berisiko terhadap kecelakaan kerja adalah pekerjaan konstruksi. Menurut (Triswandana, 2020), (Simanjuntak, 2012), dan (Alexander, 2019) Kecelakaan merupakan sesuatu peristiwa yang tidak direncanakan serta tidak diharapkan yang bisa mengganggu proses operasi, merusak harta benda, mencederai manusia, ataupun menggangu lingkungan. Kecelakaan tidak selalu mengakibatkan luka-luka, namun bisa juga mengakibatkan kerusakan material dan alat-alat yang ada, tetapi kecelakaan yang menyebabkan luka-luka ini menerima perhatian yang lebih besar (Simanjuntak, 2012). Terdapat banyak faktor yang mempengaruhi terjadinya kecelakaan kerja tersebut, seperti faktor lingkungan kerja, APD, human error, dan faktor lainnya (Asih., 2013) dan (Nur, 2007) [24]. Maka dari itu dibutuhkan adanya penerapan Keselamatan dan Kesehatan Kerja (K3) di perusahaan konstruksi ataupun perusahaan-perusahaan lainnya.

K3 merupakan kebutuhan pekerja, pengusaha, dan pemerintah (Septiani, 2016). K3 merupakan salah satu upaya dalam pencegahan kecelakaan kerja, penyakit akibat kerja, ledakan, kebakaran, dan pencemaran lingkungan kerja yang penerapannya menurut jenis dan sifat atau kegiatan pekerjaan serta kondisi lingkungan kerja (Aini, 2019). Keselamatan kerja di Indonesia telah lama mendapat perhatian dan dukungan dari Pemerintah sejak ditetapkannya UndangUndang Keselamatan Kerja Nomor 1 Tahun 1970 (Pradipta, 2015). Penerapan Sistem 
Manajemen Keselamatan dan Kesehatan Kerja (SMK3) sangat penting bagi perusahaan maupun bagi pekerja karena bertujuan untuk memberikan suasana lingkungan dan kondisi kerja yang baik, nyaman dan aman serta dapat menghindari kecelakaan dan penyakit kerja (Nurainiyah \& Agustapraja, 2019) dan juga berguna untuk mengidentifikasi risiko atau bahaya yang terdapat dalam suatu pekerjaan sehingga risiko tersebut dapat dikendalikan menggunakan metode-metode yang ada untuk mengurangi maupun mengeliminasi dampaknya (Triswandana \& Armaeni, 2020). Maka dari itu tenaga kerja perlu memperoleh perlindungan terhadap ancaman kecelakaan maupun kesehatan dalam bekerja (Sucita \& Broto, 2011).

PT. Ravana Jaya merupakan perusahaan yang bergerak di bidang kontruksi yang membuat instalasi bangunan maupun kerangka bangunan. PT. Ravana Jaya memiliki SOP dengan standar minimal kelengkapan APD, seperti sepatu safety, sarung tangan, dan helm safety. Penerapan K3 di PT. Ravana Jaya masih tergolong kurang karena minimnya kesadaran tentang pentingya $\mathrm{K} 3$ dan manfaat dari $\mathrm{K} 3$. Sehingga para pekerja tidak menggunakan APD yang tersedia dan yang sesuai dengan pekerjaanya. Kondisi lingkungan di PT. Ravana Jaya tidak aman dan nyaman karena tidak ada jalur khusus untuk berjalan ke area pekerjaan dan area pekerjan juga berubah-ubah tidak sesuai dengan penataan perusahaan. Sehingga sering terjadi kasus kecelakaan kerja seperti yang disajikan pada tabel 1 .

Tabel 1. Kecelakaan Kerja Periode Januari 2021 - Juni 2021

\begin{tabular}{clc}
\hline No. & \multicolumn{1}{c}{ Jenis Kecelakaan } & $\begin{array}{c}\text { Jumlah } \\
\text { kejadian }\end{array}$ \\
\hline 1 & Tersandung material & 26 \\
\hline 2 & Terkena percikan gram & 29 \\
\hline 3 & $\begin{array}{l}\text { Terkena percikan api } \\
\text { las }\end{array}$ & 18 \\
\hline 4 & $\begin{array}{l}\text { Kaki tertancap gram } \\
\text { sisa material }\end{array}$ & 16 \\
\hline 5 & $\begin{array}{l}\text { Kontak langsung } \\
\text { dengan benda panas }\end{array}$ & 12 \\
\hline 6 & $\begin{array}{l}\text { Tersandung kabel dan } \\
\text { selang }\end{array}$ & 17 \\
\hline 7 & Terjepit plat material & 8 \\
\hline
\end{tabular}

Sumber : PT. Ravana Jaya
Kecelakaan kerja tersebut mengakibatkan pekerja cidera sehingga perlu pengobatan, menggangu proses bekerja, dan waktu penyelesaian pekerjaan menjadi terlambat.

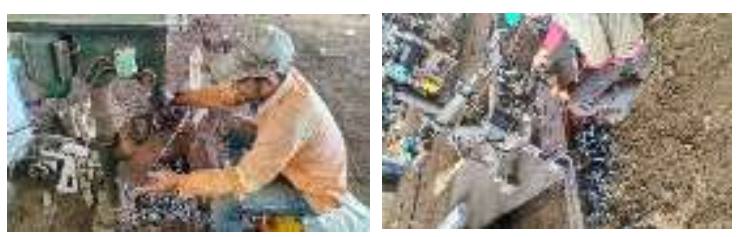

Sumber : PT. Ravana Jaya

Gambar 1. Pekerja tidak menggunakan APD

Permasalahan yang dihadapi PT. Ravana Jaya diantaranya adalah bahaya atau resiko apa saja yang terjadi di area kerja atau workshop perusahaan dan seberapa besar tingkat bahaya tersebut. Sebelum mengendalikan bahaya sebaiknya perlu diketahui terlebih dahulu akar penyebab dari bahaya atau risiko tersebut.

\section{METODE PENELITIAN}

Dalam penelitian ini metode yang digunakan adalah Hazzard Identification and Risk Assesment (HIRA) dan Fault Tree Analyzis (FTA). Metode Hazzard Identification and Risk Assesment (HIRA) merupakan metode yang digunakan untuk mengidentiifikasi potensipotensi bahaya yang terdapat pada area kerja menggunakan cara mendefinisikan karakteristik bahaya-bahaya yang mungkin terjadi pada area tersebut dan mengevaluasi risiko yang terjadi melalui penilaian risiko dengan menggunakan matriks penilaian risiko (Darmawan, 2017) dan (Efendi, 2020).

Proses menggunakan Hazzard Identification and Risk Assesment (HIRA) terdiri dari 2 yaitu :
a Hazzard Identification (identifikasi bahaya)
b Risk assessment (penilaian risiko)

Dalam proses penilaian risiko menggunakan 2 skala yaitu skala parameter dan skala risk matrix yang dipakai di standar Australia dan New Zealand (Standard Australia License, 1999) sebagaimana disajikan pada Tabel 2, 3 dan Tabel 4.

Tabel 2. Skala Tingkat Kemungkinan Kejadian (Likelihood) 


\begin{tabular}{|c|c|c|}
\hline Tingkat & Deskripsi & Keterangan \\
\hline 5 & $\begin{array}{l}\text { Almost } \\
\text { Certain }\end{array}$ & \begin{tabular}{lr}
\multicolumn{3}{l}{ Terdapat satu atau } \\
lebih kejadian \\
dalam sehari \\
(Pasti $\quad$ terjadi \\
dalam & semua \\
kondisi) & \\
\end{tabular} \\
\hline 4 & Likely & $\begin{array}{l}\text { Terdapat satu atau } \\
\text { lebih kejadian } \\
\text { dalam seminggu } \\
\text { (mungkin terjadi } \\
\text { dalam semua } \\
\text { kondisi) }\end{array}$ \\
\hline 3 & Passible & $\begin{array}{l}\text { Terdapat satu atau } \\
\text { lebih kejadian } \\
\text { dalam sebulan } \\
\text { (mungkin terjadi } \\
\text { dalam dibeberapa } \\
\text { kondisi tertentu) }\end{array}$ \\
\hline 2 & Unlikely & $\begin{array}{l}\text { Terdapat satu atau } \\
\text { lebih kejadian } \\
\text { dalam setahun } \\
\text { (kemungkinanya } \\
\text { kecil terjadi } \\
\text { dalam beberapa } \\
\text { kondisi tertentu) }\end{array}$ \\
\hline 1 & Rare & $\begin{array}{l}\text { Terdapat kurang } \\
\text { dari 1 kejadian } \\
\text { dalam setahun } \\
\text { (Kemungkinan } \\
\text { terjadi hanya pada } \\
\text { kondisi khusus) }\end{array}$ \\
\hline
\end{tabular}

Sumber : AS/NZS $4360: 1999$

Tabel 3. Skala Tingkat Keparahan (Severity)

\begin{tabular}{|c|c|c|}
\hline Tingkat & Deskripsi & Keterangan \\
\hline 1 & Insignifican & $\begin{array}{lr}\text { Tidak } & \text { terjadi } \\
\text { cidera } & \text { dan } \\
\text { kerugian } & \\
\text { perusahaan } & \\
\text { sedikit } & \end{array}$ \\
\hline 2 & Minor & $\begin{array}{l}\text { Cidera ringan dan } \\
\text { kerugian } \\
\text { perusahan sedang }\end{array}$ \\
\hline 3 & Moderate & $\begin{array}{lr}\text { Cidera } & \text { sedang } \\
\text { perlu } & \text { perawatan } \\
\text { medis } & \text { dan } \\
\text { kerugian } & \text { cukup } \\
\text { besar } & \\
\end{array}$ \\
\hline 4 & Major & $\begin{array}{l}\text { Cidera berat dan } \\
\text { kerugian } \\
\text { perusaahn besar }\end{array}$ \\
\hline 5 & Catasirophi & $\begin{array}{l}\text { Fatal dan } \\
\text { kerugian }\end{array}$ \\
\hline
\end{tabular}

\begin{tabular}{c}
\hline $\begin{array}{l}\text { perusahaan sangat } \\
\text { besar }\end{array}$ \\
\hline Sumber : AS/NZS $4360: 1999$
\end{tabular}

Tabel 4. Skala Tingkat Resiko (Risk Matrix)

\begin{tabular}{|c|c|c|c|c|c|}
\hline \multirow{3}{*}{ Likelihood } & \multicolumn{5}{|c|}{ Severity } \\
\hline & 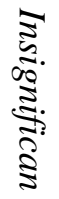 & 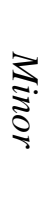 & $\begin{array}{l}\frac{3}{0} \\
\frac{2}{2} \\
\frac{2}{2}\end{array}$ & $\frac{3}{2}$ & 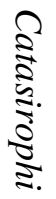 \\
\hline & 1 & 2 & 3 & 4 & 5 \\
\hline $\begin{array}{c}5 \text { (Almost } \\
\text { Certain) }\end{array}$ & $\mathrm{H}$ & $\mathrm{H}$ & $\mathrm{E}$ & $\mathrm{E}$ & $\mathrm{E}$ \\
\hline 4 (Likely) & M & $\mathrm{H}$ & $\mathrm{H}$ & $\mathrm{E}$ & $\mathrm{E}$ \\
\hline 3 (Passible) & $\mathrm{L}$ & $\mathrm{M}$ & $\mathrm{H}$ & $\mathrm{E}$ & $\mathrm{E}$ \\
\hline $\begin{array}{c}2 \\
\text { (Unlikely) }\end{array}$ & $\mathrm{L}$ & $\mathrm{L}$ & M & $\mathrm{H}$ & $\mathrm{E}$ \\
\hline $\begin{array}{c}1 \\
\text { (Rare) }\end{array}$ & $\mathrm{L}$ & $\mathrm{L}$ & M & $\mathrm{H}$ & $\mathrm{E}$ \\
\hline
\end{tabular}

Sumber : AS/NZS $4360: 1999$

$\begin{array}{ll}\mathrm{E} & : \text { Extreme Risk } \\ \mathrm{H} & : \text { High Risk } \\ \mathrm{M} & \text { : Moderate Risk } \\ \mathrm{L} & \text { : Low Risk }\end{array}$

Setelah mengetahui tingkat risiko HIRA yang paling tinggi kemudian dianalisis menggunakan metode Fault Tree Analysis (FTA). Fault Tree Analysis (FTA) adalah suatu metode analisis resiko dengan model grafik serta logika yang menunjukan gabungan dari kejadian-kejadian yang memungkinkan akan mengakibatkan kejadian yang tidak di inginkan (Krisna, 2018) dan (Nur \& Ariwibowo, 2007). Bell Telephone Laboratories memperkenalkan metode Fault Tree Analysis (FTA) pertama kali pada tahun 1962 (Pradipta, 2015).

Menggunakan metode Fault Tree Analysis (FTA) dapat mengetahui faktor dan gabungan penyebab yang bisa mengakibatkan terjadinya kecelakaan kerja. Metode ini dapat digunakan pada pekerjaan kontruksi, pekerjaan ketinggian dan pekerjaan pembangunan, dll. Maka dari itu digunakan metode ini untuk mengetahui faktor dan gabungan penyebab yang tersembunyi yang dapat mengakibatkan terjadinya kecelakaan sehingga diharapkan kecelakaan tersebut dapat dihindari (Nur \& Halbi, 2020). 


\section{HASIL DAN PEMBAHASAN}

\subsection{Hazzard Identification and Risk}

\section{Assesment (HIRA)}

Data dalam penelitian ini didapatkan dengan cara observasi, kuisioner dan wawancara yaitu penilaian resiko potensi bahaya yang didapat dari kepala lapangan dan 8 pekerja PT. Ravana Jaya. Berikut merupakan potensi bahaya yang ada pada workshop PT. Ravana Jaya dan penilaian risiko hasil dari 9 responden yang di tampilkan di tabel 5.

Tabel 5. Penilaian Resiko Potensi Bahaya Dan

\begin{tabular}{|c|c|c|c|c|c|c|}
\hline \multicolumn{7}{|c|}{ Penentuan Resiko } \\
\hline$\underset{8}{8}$ & 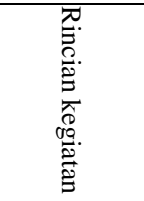 & 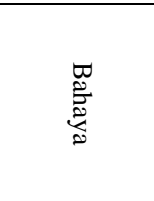 & 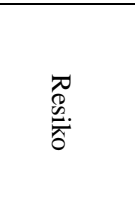 & 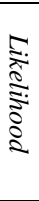 & 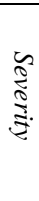 & 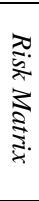 \\
\hline \multirow{8}{*}{ 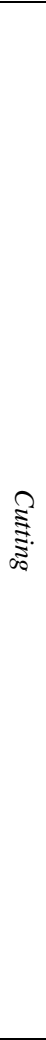 } & \multirow{4}{*}{$\begin{array}{c}\text { Memotong } \\
\text { material } \\
\text { (mesin } \\
\text { potong) }\end{array}$} & $\begin{array}{l}\text { Pekerja } \\
\text { kontak } \\
\text { dengan } \\
\text { benda panas }\end{array}$ & $\begin{array}{l}\text { Melepuh, } \\
\text { lecet, luka } \\
\text { bakar }\end{array}$ & 4 & 3 & $\mathrm{H}$ \\
\hline & & $\begin{array}{l}\text { Tangan } \\
\text { pekerja } \\
\text { terkena } \\
\text { mesin } \\
\text { cutting }\end{array}$ & $\begin{array}{l}\text { Lecet, } \\
\text { Luka } \\
\text { tergores, } \\
\text { tangan } \\
\text { terpotong }\end{array}$ & 2 & 4 & $\mathrm{H}$ \\
\hline & & $\begin{array}{l}\text { Pekerja } \\
\text { terkena } \\
\text { percikan api }\end{array}$ & $\begin{array}{l}\text { Memar, } \\
\text { lecet, luka } \\
\text { tergores, } \\
\text { luka bakar }\end{array}$ & 4 & 3 & $\mathrm{H}$ \\
\hline & & $\begin{array}{l}\text { Pekerja } \\
\text { tersandung }\end{array}$ & $\begin{array}{l}\text { Memar, } \\
\text { lecet, luka } \\
\text { gores }\end{array}$ & 5 & 2 & $\mathrm{H}$ \\
\hline & \multirow{4}{*}{$\begin{array}{l}\text { Memotong } \\
\text { material } \\
\text { (mesin } \\
\text { potong las) }\end{array}$} & $\begin{array}{l}\text { Pekerja } \\
\text { terpapar } \\
\text { dengan } \\
\text { benda panas }\end{array}$ & $\begin{array}{l}\text { Melepuh, } \\
\text { lecet, luka } \\
\text { bakar }\end{array}$ & 5 & 3 & $\mathrm{E}$ \\
\hline & & $\begin{array}{l}\text { Tangan } \\
\text { pekerja } \\
\text { terkena api } \\
\text { las saat } \\
\text { menyalakan }\end{array}$ & $\begin{array}{l}\text { Luka } \\
\text { bakar, } \\
\text { memar }\end{array}$ & 3 & 3 & $\mathrm{H}$ \\
\hline & & $\begin{array}{l}\text { Pekerja } \\
\text { terkena } \\
\text { percikan api } \\
\text { las }\end{array}$ & $\begin{array}{l}\text { Memar, } \\
\text { lecet, luka } \\
\text { tergores, } \\
\text { luka bakar }\end{array}$ & 5 & 2 & $\mathrm{H}$ \\
\hline & & $\begin{array}{l}\text { Pekerja } \\
\text { tersandung }\end{array}$ & $\begin{array}{l}\text { Memar, } \\
\text { lecet, luka } \\
\text { gores }\end{array}$ & 5 & 1 & $\mathrm{H}$ \\
\hline \multirow[b]{2}{*}{ 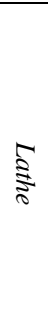 } & \multirow[b]{2}{*}{$\begin{array}{l}\text { Bubut } \\
\text { material }\end{array}$} & $\begin{array}{l}\text { Kaki } \\
\text { tertancap } \\
\text { gram sisa } \\
\text { material } \\
\end{array}$ & $\begin{array}{l}\text { Kulit } \\
\text { sobek, } \\
\text { lecet, luka } \\
\text { dalam }\end{array}$ & 5 & 2 & $\mathrm{H}$ \\
\hline & & $\begin{array}{l}\text { Pekerja } \\
\text { terkena } \\
\text { percikan } \\
\text { gram }\end{array}$ & $\begin{array}{l}\text { Luka } \\
\text { gores, } \\
\text { kebutaan } \\
\text { jika } \\
\text { terkena } \\
\text { mata }\end{array}$ & 5 & 3 & $\mathrm{E}$ \\
\hline
\end{tabular}

\begin{tabular}{|c|c|c|c|c|c|c|}
\hline & & $\begin{array}{l}\text { Pekerja } \\
\text { terjepit plat } \\
\text { material }\end{array}$ & $\begin{array}{l}\text { Memar, } \\
\text { lecet, } \\
\text { patah } \\
\text { tulang }\end{array}$ & 2 & 3 & M \\
\hline & & $\begin{array}{l}\text { Pekerja } \\
\text { terkena mata } \\
\text { pisau }\end{array}$ & $\begin{array}{l}\text { Luka } \\
\text { gores, } \\
\text { lecet, } \\
\text { patah } \\
\text { tulang }\end{array}$ & 2 & 2 & $\mathrm{~L}$ \\
\hline \multirow{6}{*}{ 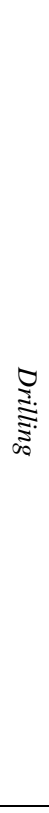 } & \multirow{6}{*}{$\begin{array}{l}\text { Melubangi } \\
\text { material }\end{array}$} & $\begin{array}{l}\text { Pekerja } \\
\text { tersandung }\end{array}$ & $\begin{array}{l}\text { Memar, } \\
\text { keseleo, } \\
\text { lecet }\end{array}$ & 5 & 2 & $\mathrm{H}$ \\
\hline & & $\begin{array}{l}\text { Pekerja } \\
\text { terkena mata } \\
\text { bor }\end{array}$ & $\begin{array}{l}\text { Luka } \\
\text { gores, } \\
\text { lecet, } \\
\text { patah } \\
\text { tulang }\end{array}$ & 1 & 2 & $\mathrm{~L}$ \\
\hline & & $\begin{array}{l}\text { Pekerja } \\
\text { terjepit } \\
\text { material }\end{array}$ & $\begin{array}{l}\text { Memar, } \\
\text { lecet, } \\
\text { patah } \\
\text { tulang }\end{array}$ & 2 & 2 & $\mathrm{~L}$ \\
\hline & & $\begin{array}{l}\text { Pekerja } \\
\text { terkena } \\
\text { percikan } \\
\text { gram }\end{array}$ & $\begin{array}{l}\text { Luka } \\
\text { gores, } \\
\text { kebutaan } \\
\text { jika } \\
\text { terkena } \\
\text { mata }\end{array}$ & 5 & 2 & $\mathrm{H}$ \\
\hline & & $\begin{array}{l}\text { Pekerja } \\
\text { terkena plat } \\
\text { yang terjatuh }\end{array}$ & $\begin{array}{l}\text { Memar, } \\
\text { patah } \\
\text { tulang }\end{array}$ & 1 & 3 & M \\
\hline & & $\begin{array}{l}\text { Kaki } \\
\text { tertancap } \\
\text { gram sisa } \\
\text { material }\end{array}$ & $\begin{array}{l}\text { Kulit } \\
\text { sobek, } \\
\text { lecet, luka } \\
\text { dalam }\end{array}$ & 5 & 3 & $\mathrm{E}$ \\
\hline \multirow{4}{*}{ 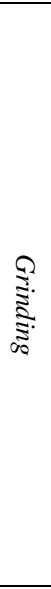 } & \multirow{4}{*}{$\begin{array}{l}\text { Menggerinda } \\
\text { material }\end{array}$} & $\begin{array}{l}\text { Tangan } \\
\text { pekerja } \\
\text { terkena } \\
\text { gerinda }\end{array}$ & $\begin{array}{l}\text { Lecet, } \\
\text { luka } \\
\text { tergores, } \\
\text { tangan } \\
\text { terpotong }\end{array}$ & 2 & 4 & $\mathrm{H}$ \\
\hline & & $\begin{array}{l}\text { Terkena } \\
\text { percikan api } \\
\text { dari mesin } \\
\text { gerinda }\end{array}$ & $\begin{array}{l}\text { Lecet, } \\
\text { luka } \\
\text { bakar, } \\
\text { kebutaan } \\
\text { jika } \\
\text { terkena } \\
\text { mata } \\
\end{array}$ & 5 & 2 & $\mathrm{H}$ \\
\hline & & $\begin{array}{l}\text { Pekerja } \\
\text { tertimpa } \\
\text { material } \\
\end{array}$ & $\begin{array}{l}\text { Kematian, } \\
\text { patah } \\
\text { tulang }\end{array}$ & 1 & 3 & M \\
\hline & & $\begin{array}{l}\text { Pekerja } \\
\text { tersandung } \\
\text { material } \\
\end{array}$ & $\begin{array}{l}\text { Memar, } \\
\text { lecet, luka } \\
\text { gores }\end{array}$ & 5 & 2 & $\mathrm{H}$ \\
\hline \multirow{6}{*}{ 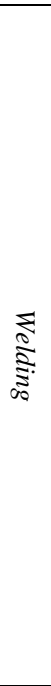 } & \multirow{6}{*}{$\begin{array}{l}\text { Mengelas } \\
\text { material }\end{array}$} & $\begin{array}{l}\text { Pekerja } \\
\text { kontak } \\
\text { dengan } \\
\text { benda panas } \\
\end{array}$ & $\begin{array}{l}\text { Melepuh, } \\
\text { lecet, luka } \\
\text { bakar }\end{array}$ & 5 & 3 & $\mathrm{E}$ \\
\hline & & $\begin{array}{l}\text { Pekerja } \\
\text { terkena } \\
\text { percikan api } \\
\text { las }\end{array}$ & $\begin{array}{l}\text { Luka } \\
\text { bakar, } \\
\text { melepuh }\end{array}$ & 5 & 2 & $\mathrm{H}$ \\
\hline & & $\begin{array}{l}\text { Pekerja } \\
\text { menghirup } \\
\text { asap las }\end{array}$ & $\begin{array}{l}\text { Sakit } \\
\text { paru-paru, } \\
\text { sesak } \\
\text { nafas }\end{array}$ & 5 & 2 & $\mathrm{H}$ \\
\hline & & $\begin{array}{l}\text { Pekerja } \\
\text { tersandung }\end{array}$ & $\begin{array}{l}\text { Memar, } \\
\text { keseleo, } \\
\text { lecet }\end{array}$ & 5 & 2 & $\mathrm{H}$ \\
\hline & & $\begin{array}{l}\text { Mata pekerja } \\
\text { terpantul } \\
\text { sinar las } \\
\end{array}$ & $\begin{array}{l}\text { Sakit } \\
\text { mata, } \\
\text { katarak }\end{array}$ & 4 & 3 & $\mathrm{H}$ \\
\hline & & $\begin{array}{l}\text { Pekerja } \\
\text { tertimpa } \\
\text { material }\end{array}$ & $\begin{array}{l}\text { Kematian, } \\
\text { patah } \\
\text { tulang }\end{array}$ & 1 & 4 & $\mathrm{H}$ \\
\hline
\end{tabular}


Sumber : pengolahan data dari observasi, kuisioner dan wawancara

\subsection{Fault Tree Analysis (FTA)}

Selanjutnya peneliti menganalisis dengan metode Fault Tree Analysis (FTA) untuk mengetahui faktor dan kombinasi penyebab yang dapat menyebabkan terjadinya kecelakaan kerja.

\section{A. Area Cutting}

Berikut analisis akar penyebab terjadinya kecelakaan kerja dengan metode FTA pada PT. Ravana Jaya di area Cutting yang di tampilkan pada gambar 2 .

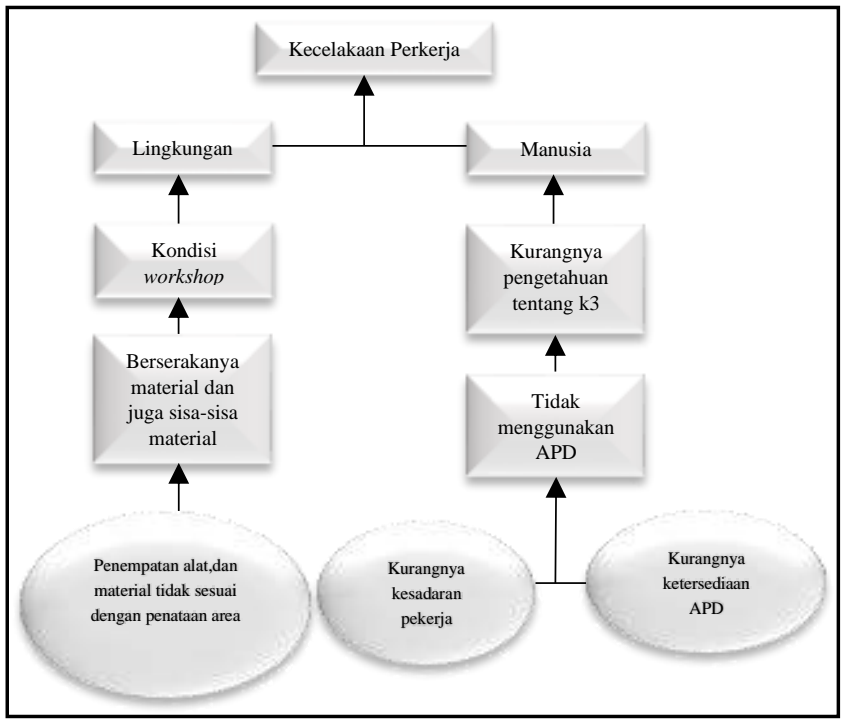

(Sumber : pengolahan data dari observasi, kuisioner dan wawancara)

Gambar 2. Fault Tree Analysis area Cutting

Hasil analisis menggunakan metode FTA pada area Cutting, dapat diketahui akar penyebab yang menyebabkan kecelakaan kerja pada PT. Ravana Jaya. Dilihat dari segi manusia, penyebab dari kecelakaan kerja ini dimana para pekerja tidak menggunakan APD yang seharusnya digunakan untuk melindungi anggota tubuh serta kurangnya pengetahuan tentang K3 dalam bekerja sehingga kurangnya kesadaran para pekerja tidak memakai APD yang tersedia dengan jumlah yang terbatas.
Dari segi lingkungan akar penyebab dari kecelakaan kerja dimana kondisi lingkungan kerja penempatan alat dan material tidak sesuai dengan penataan area sehingga menyebabkan pekerja tersandung, terkena percikan api, dan terpapar benda panas.

\section{B. Area Lathe}

Berikut analisis akar penyebab terjadinya kecelakaan kerja dengan metode FTA pada PT. Ravana Jaya di area Lathe yang di tampilkan pada gambar 3 .

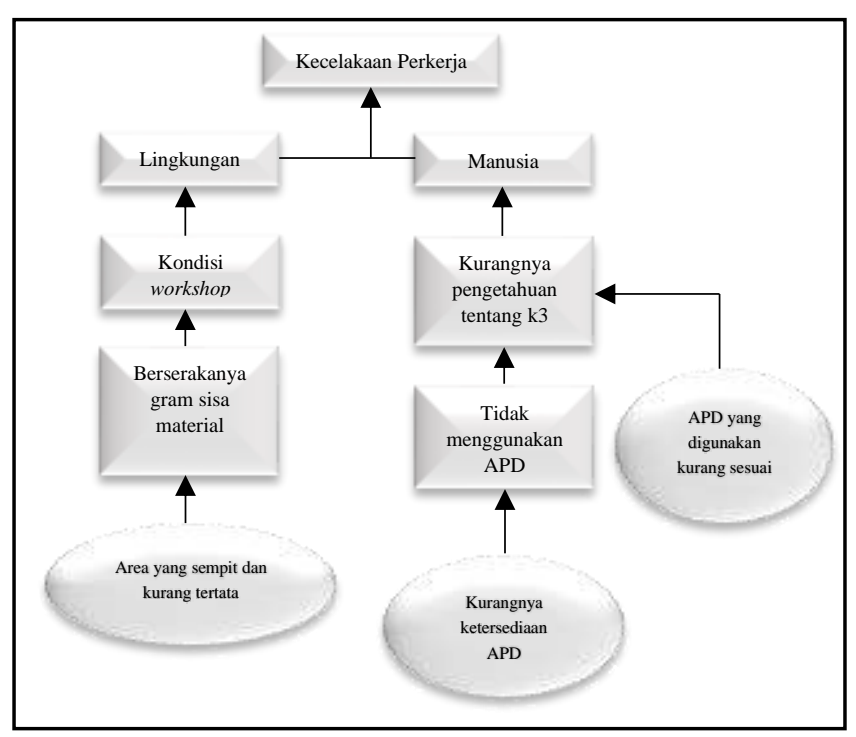

(Sumber : pengolahan data dari observasi, kuisioner dan wawancara)

Gambar 3. Fault Tree Analysis area lathe

Hasil analisis menggunakan metode FTA pada area Lathe, dapat diketahui akar penyebab yang menyebabkan kecelakaan kerja pada PT. Ravana Jaya. Dilihat dari segi manusia, penyebab dari kecelakaan kerja kurangnya pengetahuan tentang K3 dalam bekerja sehingga para pekerja tidak menggunakan APD yang sesuai untuk melindungi anggota tubuh dan kurangnya keersediaan APD itu sendiri.

Dari segi lingkungan akar penyebab dari kecelakaan kerja dimana kondisi area kerja yang sempit dan kurang tertata sehingga menyebabkan pekerja terjepit, tertancap gram dan terkena percikan gram.

\section{Area Drilling}

Berikut analisis akar penyebab terjadinya kecelakaan kerja dengan metode FTA pada PT. 


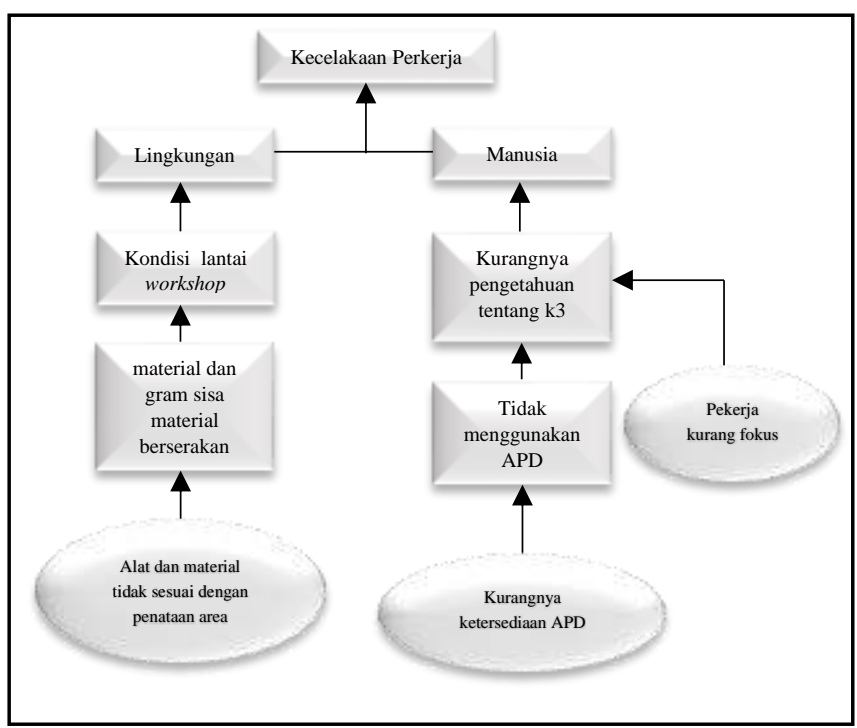

Ravana Jaya di area Drilling yang di tampilkan pada gambar 4.

(Sumber : pengolahan data dari observasi, kuisioner dan wawancara)

\section{Gambar 4. Fault Tree Analysis area Drilling}

Hasil analisis menggunakan metode FTA pada area Driling, dapat diketahui akar penyebab yang menyebabkan kecelakaan kerja pada PT. Ravana Jaya. Dilihat dari segi manusia, penyebab dari kecelakaan kerja ini dimana para pekerja kurang focus saat bekerja dan juga tidak menggunakan APD yang seharusnya digunakan untuk melindungi anggota tubuh karena kurangnya pengetahuan tentang K3 dalam bekerja.

Dari segi lingkungan akar penyebab dari kecelakaan kerja dimana kondisi lingkungan kerja alat dan material tidak sesuai dengan penataan area sehingga menyebabkan terjadinya kecelakaan kerja berupa tertancap gram, tersandung dan terkena percikan.

\section{Area Grinding}

Berikut analisis akar penyebab terjadinya kecelakaan kerja dengan metode FTA pada PT. Ravana Jaya di area Grinding yang di tampilkan pada gambar 5 .

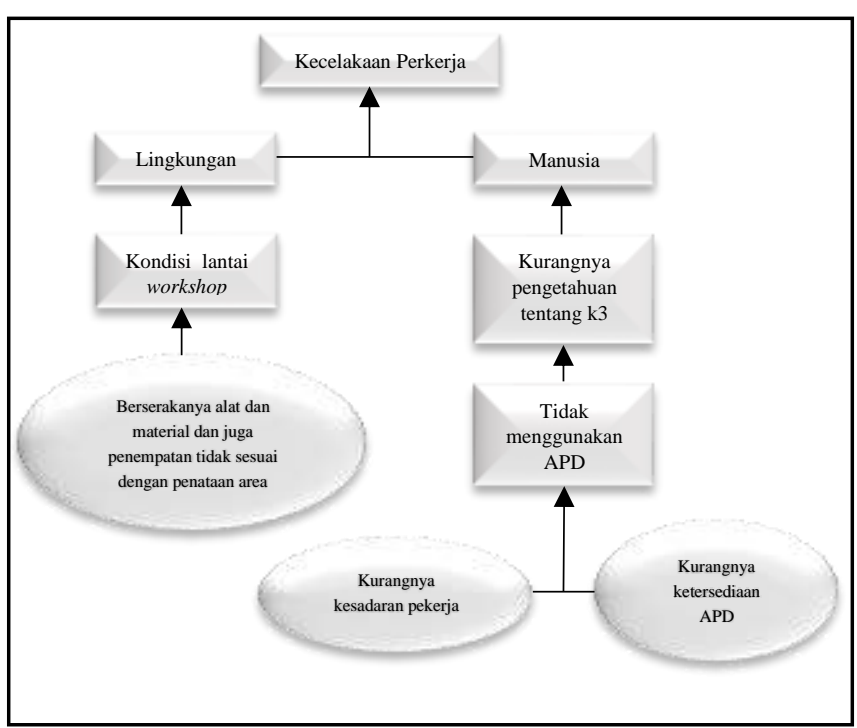

(Sumber : pengolahan data dari observasi, kuisioner dan wawancara)

Gambar 5. Fault Tree Analysis area Grinding

Hasil analisis menggunakan metode FTA pada area Grinding, dapat diketahui akar penyebab yang menyebabkan kecelakaan kerja pada PT. Ravana Jaya. Dilihat dari segi manusia, penyebab dari kecelakaan kerja dimana para pekerja kurang pengetahuan tentang K3 dalam bekerja sehingga pekerja tidak menggunakan APD karena kurangnya APD dan kurangnya kesadaran dari pekerja untuk menggunakan APD itu sendiri.

Dari segi lingkungan akar penyebab dari kecelakaan kerja dimana kondisi lingkungan kerja berseraka alat dan material dan juga penempatan tidak sesuai dengan penataan area sehingga menyebabkan pekerja tersandung dan terkena percikan api.

\section{E. Area Welding}

Berikut analisis akar penyebab terjadinya kecelakaan kerja dengan metode FTA pada PT. Ravana Jaya di area Welding yang di tampilkan pada gambar 6 . 


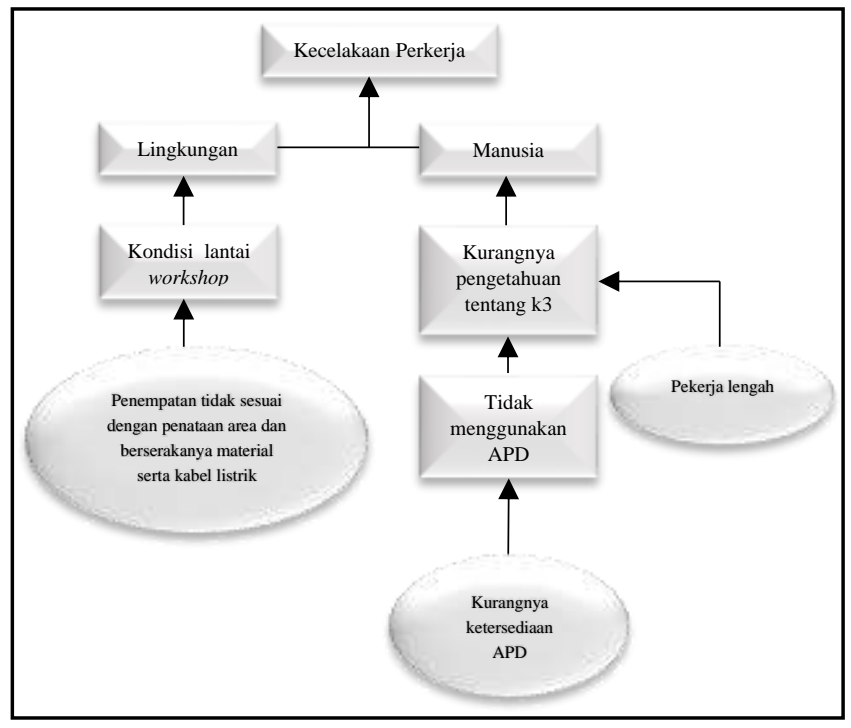

(Sumber : pengolahan data dari observasi, kuisioner dan wawancara)

Gambar 6. Fault Tree Analysis area Welding

Hasil analisis menggunakan metode FTA pada area Welding, dapat diketahui akar penyebab yang menyebabkan kecelakaan kerja pada PT. Ravana Jaya. Dilihat dari segi manusia, penyebab dari kecelakaan kerja ini dimana para pekerja tidak menggunakan APD yang seharusnya digunakan untuk melindungi anggota tubuh dan kurangnya pengetahuan tentang K3 dalam bekerja sehingga pekerja tidak hati-hati dan lengah saat bekerja.

Dari segi lingkungan akar penyebab dari kecelakaan kerja dimana kondisi lingkungan kerja penempatan alat tidak sesuai dengan penataan area dan berserakanya material serta kabel listrik sehingga menyebabkan terjadinya kecelakaan kerja seperti tersandung.

\section{SIMPULAN}

Kesimpulan dari penelitian yang dilakukan di PT. Ravana Jaya terdapat 28 identifiksai bahaya. Dengan penilaian risiko sebagai berikut: 4 dengan kategori extreme risk (E), 18 dengan kategori high risk (H), 3 dengan kategori medium risk $(\mathrm{M})$ dan 3 dengan kategori low risk (L).

Akar penyebab dari kecelakaan kerja terdapat 2 aspek yaitu manusia dan lingkungan dari segi manusia pekerja kurang pengetahuan tentang K3 sehinga pekerja tidak memakai APD, serta kurangnya APD itu sendiri. Dari segi lingkungan kerja area kerja alat dan

material tidak sesuai dengan penataan workshop sehingga tidak ada jalan bagi pengguna jalan atau jalanya berubah-ubah.

Dilihat dari akar penyebab dan kombinasi kecelakaan kerja yang terjadi, perusahaan segera memberi pelatihan tentang K3 kepada para pekerja dan memberlakukan SOP yang sudah ada, setelah memberi pelatihan perusahaan tetap harus mengawasi para pekerja dalam menggunakan APD dan menaati SOP. Perusahaan juga segera menata ulang area kerja agar tidak berantakanya alat dan material serta tidak berserakanya sisa gram sehingga kecelakaan bisa di minimalisir mungkin bisa sampai zero defect.

\section{PUSTAKA ACUAN}

Aini, N., Rahmawati, F., Setyono, K. J., Teknik, J., Politeknik, S., Semarang, N., \& Inspection, S. (2019). Peningkatan Produktivitas Kerja Melalui Penerapan Program K3 Di Lingkungan Konstruksi. Bangun Rekaprima, 5(1), 1-12. https://doi.org/10.32497/bangunrekaprim a.v5i1.1404

Alexander, H., Nengsih, S., \& Guspari, O. (2019). Kajian Keselamatan dan Kesehatan Kerja ( K3 ) Konstruksi Balok Pada Konstruksi Bangunan Gedung. Jurnal Ilmiah Poli Rekayasa, 15(1), 39. https://doi.org/10.30630/jipr.15.1.140

Alfons Willyam Sepang Tjakra, B. J., Ch Langi, J. E., \& O Walangitan, D. R. (2013). Manajemen Risiko Keselamatan Dan Kesehatan Kerja (K3) Pada Proyek Pembangunan Ruko Orlens Fashion Manado. Jurnal Sipil Statik, 1(4), 282288.

Asih, T. N., Mahbubah, N. A., \& Fathoni, M. Z. (2013). Identifikasi Bahaya Dan Penilaian Resiko Keselamatan Dan Kesehatan Kerja (K3) Pada Proses Fabrikasi Dengan Menggunakan Metode Hirarc (Studi Kasus PT.Ravana Jaya). JUSTI (Jurnal Sitem Dan Teknik Industri), 42-48.

Darmawan, R., Ummi, N., \& Umyati, A. (2017). Identifikasi risiko kecelakaan kerja dengan metode hazard identification and risk assessment (hira) di area batching plant PT XYZ. Teknik Industri, 5(3), 308- 
313.

Efendi, A., Nugroho, Y. S., \& Fahmi, M. (2020). Analisis Aspek Kesehatan dan Keselamatan Kerja di Laboratorium Motor Bakar. Jurnal Dinamika Vokasional Teknik Mesin, 5(1), 27-33. https://doi.org/10.21831/dinamika.v5i1.3 0989

Krisna, L. I., Darsini, \& Komariah, A. (2018). Analisis Penerapan Program Keselamatan Kerja Dalam Usaha Meningkatkan Produktivitas Kerja Dengan Pendekatan Fault Tree Analysis Di PT.Nagabhuana Aneka Piranti Wonogiri.

Mandagi, Rantung, \& Malingkus. (2013). Keselamatan Dan Kesehatan Kerja Pada Pelaksanaan Proyek Kontruksi (Studi Kasus: Proyek PT. Trakindo Utama). Jurnal Sipil Statik, 1(6), 430-433. https://doi.org/10.4135/9781848608399.n 25

Nur, M., \& Ariwibowo, O. (2007). Analisis Kecelakaan Kerja Dengan Menggunakan Metode FTA Dan 5s di PT.Jingga Perkasa Printing. Hawley's Condensed Chemical Dictionary, 4(1), 55-63. https://doi.org/10.1002/9780470114735.h awley 14577

Nur, M., \& Halbi, S. (2020). Analisa Lingkungan Kerja Dan Kesehatan, Keselamatan Kerja ( K3) (Studi Kasus: PT. Asrindo Citraseni Satria). SPECTA Journal of Technology, 3(2), 27-35. https://doi.org/10.35718/specta.v3i2.151

Nurainiyah, \& Agustapraja, H. R. (2019). PENERAPAN STANDART KESELAMATAN DAN KESEHATAN KERJA (K3) PROYEK JASA KONSTRUKSI (Studi Kasus: Pembangunan Gedung Kantor Pemkab Lamongan). Jurnal CIVILLa Vol, 4(1), 214-219.

Pradipta, H., Unas, S. El, \& Hasyim, M. H. (1970). Analisa Kesehatan Dan Keselamatan Kerja Proyek Menggunakan Fault Tree Analysis (FTA) Studi Kasus Pada Proyek Jalan Hotmix Dinas Pekerjaan Umum Kabupaten Sumbawa. Kaos GL Dergisi, 2(October), 765-770.

Rifani, Y., Mulyani, E., \& Pratiwi, R. (2018). Penerapan Konstruksi Dengan Menggunakan Metode HIRARC Pada Pekerjaan Akses Jalan Masuk. Jurnal
Mahasiswa Teknik Sipil Universitas Tanjungpura, 5(2), 1-12. https://dx.doi.org/10.26418/jelast.v5i2.26 373

Septiani, Y., Widjasena, B., \& Wahyuni, I. (2016). Analisis Kompetensi Safety Communication Petugas Keselamatan Dan Kesehatan Kerja (K3) Konstruksi Pt. $\mathrm{X}$ Kota Semarang. Jurnal Kesehatan Masyarakat (e-Journal), 4(3), 634-645.

Simanjuntak, M. R. A., \& Praditya, R. (2012). Identifikasi Penyebab Risiko Kecelakaan Kerja Pada Kegiatan Konstruksi Bangunan Gedung Di DKI Jakarta. Jurnal Ilmiah Media Engineering, 2(2), 85-99.

Standard Australia License. (1999). Standard Australia Licence 1999. As/Nzs 4360:1999, 52. http://www.epsonet.eu/mediapool/72/723 588/data/2017/AS_NZS_43601999_Risk_management.pdf

Sucita, I. K., \& Broto, A. B. (2011). Identifikasi dan Penanganan Risiko K3 pada Proyek Konstruksi Gedung. Poli Teknologi, 10(1), 83-92.

Triswandana, I. W. G. E., \& Armaeni, N. K. (2020). Penilaian Risiko K3 Konstruksi Dengan Metode HIRARC. Jurnal Universitas Kadiri Riset Teknik Sipil, 4(1), 2581-2157. http://dx.doi.org/10.30737/ukarst.v3i2. 